\title{
ANALISIS PENGENDALIAN INTERN ASET TETAP PADA PT. HASJRAT MULTIFINANCE CABANG MANADO
}

\author{
Oleh : \\ Erwin Budiman \\ Inggriani Elim \\ Program Pendidikan Profesi Akuntansi \\ Fakultas Ekonomi dan Bisnis \\ Universitas Sam Ratulangi Manado \\ email : erwin_boanerges@yahoo.co.id
}

\begin{abstract}
Fixed assets have a very important role for any company. Hence the need for the internal control system of fixed assets aimed at ensuring the security of company property, checking the accuracy and correctness of accounting data, to help encourage compliance policy leaders are set beforehand. This study aims to determine the application of the internal control structure of fixed assets at PT. Hasjrat Multifinance Branch Manado. Data analysis method used is descriptive method is a method to describe or analyze the results of the study but not used to make broader conclusions. The data used is qualitative data with secondary data sources, data collection techniques done is documentation and interview techniques. The results of research by the author, on the analysis of internal control of fixed assets at PT. Hasjrat Multifinance Branch Manado, concluded that internal control has not been effectively implemented. It can be seen from the dual function of labor between the accounting and finance are done by one person, the absence of an audit committee that controls the activity of the company, is not implemented training programs for employees, never done a physical examination once a year for fixed assets, there is no separation capital expenditures (capex) and revenue expenditure as well as the useful life of fixed assets is up is not the removal of fixed assets.
\end{abstract}

Keywords : Internal Control, Fixed Asset, Capital Expenditure, Revenue Expenditure.

\section{PENDAHULUAN Latar Belakang}

Aset tetap (fixed asset) adalah aktiva berwujud yang diperoleh dalam bentuk siap pakai atau dengan dibangun terlebih dahulu, yang digunakan dalam operasi perusahaan, tidak dimaksudkan untuk dijual dalam rangka kegiatan normal perusahaan dan mempunyai masa manfaat lebih dari satu tahun. Aset tetap (fixed assets) adalah aktiva yang secara fisik dapat dilihat keberadaannya dan sifatnya relatif permanen serta memiliki masa kegunaan (usefull) yang panjang. Aset tetap merupakan aktiva yang berwujud (tangible assets). Aset tetap juga dapat diperoleh dengan beberapa cara seperti membeli secara tunai, membeli secara kredit atau angsuran, pertukaran, penerbitan surat berharga, dibangun sendiri, sewa guna usaha atau leasing dan donasi. Oleh karena itu perlu adanya sistem pengendalian atas aset tetap yang 
bertujuan untuk menjaga keamanan harta milik perusahaan, memeriksa ketelitian dan kebenaran data akuntansi, membantu mendorong dipatuhinya kebijakan pimpinan yang ditetapkan terlebih dahulu.

Dengan adanya sistem pengendalian intern yang baik, akan membantu pihak manajemen di dalam melakukan pengawasan, mengontrol pengeluaran biaya-biaya yang dikeluarkan dalam rangka memperoleh aset tetap, meningkatkan efisiensi operasional dan kapasitas produktif aset tetap serta memperpanjang masa manfaat aset tetap. Pengendalian intern yang baik, dapat memberikan suatu informasi atas laporan keuangan perusahaan yang mencerminkan nilai dari suatu aset tetap tersebut.

PT. Hasjrat Multifinance cabang Manado, merupakan perusahaan yang usahanya bergerak dibidang pembiayaan mobil dan motor. Perusahaan tersebut memiliki berbagai jenis aset tetap. Salah satu aset tetap yang sangat penting bagi kegiatan usaha perusahaan adalah kendaraan roda empat,kendaraan roda dua dan inventaris kantor.

\section{Tujuan Penelitian}

Untuk mengetahui penerapan struktur Pengendalian Intern Aset tetap yang dilakukan pada PT.Hasjrat Multifinance Cabang Manado.

\section{TINJAUAN PUSTAKA \\ Akuntansi}

Suwardjono (2013:4), mengatakan kata akuntansi berasal dari kata bahasa Inggris to account yang berarti memperhitungkan atau mempertangungjawabkan. Kata akuntansi sebenarnya diserap dari kata accountancy yang berarti hal-hal yang bersangkutan dengan accountant (akuntan) atau bersangkutan dengan hal-hal yang dikerjakan oleh akuntan dalam menjalankan profesinya.

Akuntansi adalah seni pencatatan, penggolongan dan peringkasan transaksi dan kejadian yang bersifat keuangan dengan cara yang berdaya guna dan dalam bentuk satuan uang dan penginterpretasian hasil proses tersebut. Pengertian seni dalam definisi tersebut dimaksudkan untuk menunjukkan bahwa akuntansi bukan merupakan ilmu pengetahuan eksata atau sains karena dalam proses penalaran dan perancangan akuntansi banyak terlibat unsur pertimbangan (judgment).

Ismail (2010:2), mengatakan akuntansi adalah seni dalam mencatat, menggolongkan dan mengikhtisarkan semua transaksi-transaksi yang terkait dengan keuangan yang telah terjadi dengan suatu cara yang bermakna dan dalam satuan uang.

\section{Pengendalian Internal}

Dinapoli (2010), mengatakan pengendalian internal adalah kegiatan atau prosedur dirancang untuk memberikan keyakinan memadai bahwa operasi akan sesuai dengan rencana yang ditetapkan.

Messier (2009:250), mengatakan pengendalian internal dapat diartikan sebagai sebagai suatu proses yang dijalankan oleh dewan komisaris, manajemen, dan personel entitas lainnya yang didesain untuk untuk memberikan keyakinan memadai tentang pencapaian tiga golongan tujuan berikut ini: keandalan pelaporan keuangan, efektivitas dan efisiensi operasi, dan kepatuhan terhadap hukum dan peraturan yang berlaku.

\section{Tujuan Pengendalian Internal}

Danang Sunyoto (2014:157), mengatakan sistem pengendalian internal terdiri atas kebijakan dan prosedur yang dirancang untuk memberikan kepastian yang layak bagi manajemen, bahwa perusahaan telah mencapai tujuan dan sasarannya. 


\section{Komponen Pengendalian Internal Committee of Supporting Organization of the Tredway Commission (COSO)}

Arens (2008), mengatakan internal control-integrated framework yang dikeluarkan oleh Committee of Supporting Organization of the Tredway Commission (COSO), yaitu kerangka kerja pengendalian yang paling luas diterima di Amerika Serikat, menguraikan lima komponen pengendalian internal .Komponen pengendalian internal COSO meliputi hal-hal berikut ini.

1. Lingkungan Pengendalian (Control Environment)

2. Penilaian Resiko (Risk Assessment)

3. Aktivitas Pengendalian (Control Activities)

4. Informasi dan Komunikasi (Information and Communication)

5. Pemantauan (monitoring)

Aktiva Tetap

Giri (2012:217), mengatakan aset tetap adalah aset yang memiliki karakteristik sebagai berikut.

1. memiliki wujud fisik

2. diperoleh untuk digunakan dalam kegiatan usaha perusahaan, dan tidak dimaksudkan untuk dijual.

Suhayati (2009: 68), mengatakan aset tetap adalah aktiva yag dapat digunakan oleh perusahaan dalam menjalankan aktivitas usaha dan sifatnya relative tetap atau jangka waktu perputarannya lebih dari satu tahun.

\section{Capital Expenditure dan Revenue Expenditure}

Hery (2011: 165-166), mengatakan pengeluaran modal (capital expenditure) adalah biaya-biaya yang dikeluarkan dalam rangka memperoleh aset tetap, meningkatkan efisiensi operasional dan kapasitas produksi aset tetap serta memperpanjang masa manfaat aset tetap. Sedangkan pengeluaran pendapatan (revenue expenditure) adalah biaya-biaya yang hanya akan memberi manfaat dalam periode berjalan, sehingga biaya-biaya yang dikeluarkan ini tidak akan dikapitalisasi sebagai aset tetap di neraca melainkan akan langsung dibebankan sebagai beban dalam laporan laba rugi periode berjalan dimana biaya tersebut terjadi.

\section{Pengendalian Internal atas Aset tetap}

Mulyadi (2009:612), mengatakan terdapat beberapa unsur pengendalian internal dalam sistem akuntansi aset tetap. Unsur-unsur tersebut sebagai berikut :

1. Organisasi

2. Sistem Otorisasi

3. Prosedur Pencatatan

4. Praktik yang sehat

Perancangan Pengujian Pengendalian Internal

Mulyadi (2009:231), mengatakan jenis pengujian pengendalian yang dapat dipilih auditor dalam pelaksanaan pengujian pengendalian adalah:

1. Permintaan Keterangan

2. Pengamatan

3. Inspeksi

4. Pelaksanaan Kembali

\section{Penelitian Terdahulu}

1. Ade Suherman (2011) dengan judul "Pengendalian Intern Aset Tetap pada PDAM Tirta Anom Banjar" Tujuan Penulis untuk mengetahui pengendalian intern aset tetap. Metode 
penelitian yang digunakan adalah metode deskriptif. Hasil dari penelitian yang dilakukan yaitu Struktur pengendalian intern aset tetap telah dilaksanakan dengan cukup memadai sehingga struktur pengendalian intern aset tetap yang efektif dan efisien belum sepenuhnya terwujud. Terdapat persamaan dan perbedaan dengan penelitian yang dilakukan penulis. Persamaannya, Penelitian sebelumnnya melakukan penelitian terhadap faktor yang sama yaitu yang berhubungan dengan aset tetap. Perbedaannya, terletak pada objek penelitian yang lebih menekankan pada lingkungan pengendalian pada PT. Hasjrat Multifinance cabang Manado.

2. Andreas Indra Cahyadi (2010) dengan judul "Analisis Pengujian Pengendalian Aset Tetap dalam mendeteksi kehilangan Aktiva Tetap pada Stikes Perdhaki Charitas Palembang" Tujuan Penulis untuk menganalisis pengendalian intern yang diterapkan di STIKES Perdhaki Charitas Palembang dalam mendeteksi kehilangan aset tetap. Metode penelitian yang digunakan adalah metode deskriptif. Hasil dari penelitian yang dilakukan yaitu struktur pengendalian intern atas aset tetap yang belum efektif, tidak adanya penomoran atau pengkodean atas aktiva tetap serta tidak dilakukan pencocokan fisik aset tetap dengan kartu aset tetap secara periodik, tidak ada asuransi atas aset tetap yang dimiliki. Persamaannya, Penelitian sebelumnnya melakukan penelitian terhadap faktor yang sama yaitu yang berhubungan dengan aset tetap. Perbedaannya, terletak pada objek penelitian yang lebih menekankan pada lingkungan pengendalian pada PT. Hasjrat Multifinance cabang Manado.

3. Muhammad Syahmi Santosa (2014) dengan judul "Peranan Sistem Pengendalian Aset Tetap terhadap Pengelolaan Aset Tetap Perusahaan Daerah Air Minum (PDAM) Pekalongan" Tujuan Penulis untuk untuk mengetahui ada atau tidaknya kelemahan sistem pengendalian intern yang ada pada PDAM Kota Pekalongan dalam mendeteksi kerusakan aset tetap maupun umur ekonomi aset tetap. Metode penelitian yang digunakan adalah metode deskriptif. Hasil penelitian menunjukkan bahwa perusahaan Daerah Air Minum (PDAM) Pekalongan mempunyai struktu pengendalian intern atas aset tetap yang efektif. Hal ini dilihat pada pelaksanaan dlm menggunakan aset tetap sesuai prosedur yg berlaku di PDAM Pekalongan. Persamaannya, Penelitian sebelumnnya melakukan penelitian terhadap faktor yang sama yaitu yang berhubungan dengan aset tetap. Perbedaannya, terletak pada objek penelitian yang lebih menekankan pada lingkungan pengendalian pada PT. Hasjrat Multifinance cabang Manado.

\section{METODE PENELITIAN}

\section{Jenis dan Sumber Data}

Data merupakan keterangan atau sumber informasi mengenai objek yang akan diteliti dan sebagai dasar dalam pengambilan keputusan. Jenis dan sumber data yang akan digunakan pada penelitian ini adalah :

1. Jenis Data

a. Data kualitatif adalah data yang bersumber dari lokasi penelitian yang diperoleh melalui wawancara dan tanya jawab dengan manajer dan karyawan yang terkait dengan objek penelitian serta penelitian secara langsung mengenai siklus kerja dalam perusahaan yang terkait dengan penelitian. Disajikan tidak dalam bentuk angka-angka.

b. Data kuantitatif adalah data yang bersumber dari data perusahaan berupa, transaksitransaksi/ jurnal pada saat dijadikan aset tetap, laporan keuangan yang terdiri dari laporan neraca, rugi/laba,arus kas dan daftar aktiva tetap perusahaan. 
Jenis data yang digunakan penulis dalam penyusunan laporan akhir ini adalah jenis data kualitatif, dengan PT. Hasjrat Multifinance Cabang Manado sebagai objek penelitian.

2. Sumber Data

Data yang digunakan dalam penelitian ini berasal dari satu sumber yaitu :

a. Data sekunder adalah data yang diperoleh dari perusahaan dalam bentuk yang sudah jadi berupa neraca, laporan laba rugi, daftar aktiva tetap, sejarah singkat berdirinya perusahaan serta struktur organisasi perusahaan.

\section{Teknik Pengumpulan Data}

1. Survey Pendahuluan

Kegiatan awal yang peneliti lakukan untuk meneliti permasalahan yang sedang dihadapi oleh perusahaan. Dalam hal ini penulis memilih PT.Hasjrat Multifinance Cabang Manado sebagai objek penelitian.

2. Survei Lapangan

Metode pengumpulan data dimana peneliti mengadakan pengamatan secara langsung ke tempat objek yang diteliti dengan cara :

a. Teknik Dokumentasi

Yaitu mengumpulkan data dan informasi melalui buku-buku, jurnal, internet dan dengan melakukan penelitian terhadap dokumen-dokumen dan laporan-laporan perusahaan yang berkaitan dengan penelitian.

b. Teknik Wawancara

Penulis melakukan tanya jawab secara langsung dengan staf bagian keuangan dan pembukuan untuk mendapatkan penjelasan mengenai cara perolehan aktiva tetap, metode penyusutan aset tetap dan cara pencatatannya pada laporan keuangan seperti laporan laba rugi dan neraca.

\section{Metode Analisis Data}

Metode yang digunakan untuk menganalisis data adalah Metode Deskriptif yaitu untuk menggambarkan secara sistematis, faktual mengenai analisis pengujian pengendalian intern aset tetap berwujud pada PT. Hasjrat Multifinance Cabang Manado.

\section{Teknik Analisis Data}

Merupakan penerapan sistem dengan menggunakan 5 (lima) unsur pengendalian internal yang berhubungan dengan masalah yang diteliti, adalah :

1. Lingkungan Pengendalian

2. Penilaian Resiko

3. Aktivitas Pengendalian

4. Informasi dan Komunikasi

5. Pengawasan

\section{HASIL PENELITIAN DAN PEMBAHASAN Hasil Penelitian}

PT. Hasjrat Multifinance ini berlokasi di Jl. Jend. Sudirman Manado, pertama kali didirikan dengan Akte Notaris Romanus Harmaka Hardaseputra, SH di Manad, Akte nomor 7 tanggal 7 September 1990 dengan memakai nama Perseroan Terbatas" PT. Hasjrat Finance Company" dengan modal dasar perseroan yaitu berjumlah Rp. 20.000.000.000 terbagi atas 20.000.000 lembar saham. Dan kemudian diadakan perubahan pada tanggal 21 November 1990 dengan akte nomor 23 yang dibuat oleh Notaris Romanus Harmaka Hardaseputra, SH dengan nama “PT. Hasjrat Multifinance". Selanjutnya pada tanggal 4 Januari 1991 telah diadakan 
perubahan akte dihadapan Notaris Romanus Harmaka Hardaseputra, SH akte nomor 2 tentang perubahan Anggaran Dasar PT.Hasjrat Multifinance.

PT. Hasjrat Multifinance ini adalah perusahaan yang bergerak dibidang pembiayaan. Maksud dari perusahaan pembiayaan adalah suatu bentuk perusahaan yang memfokuskan bisnisnya kepada pemberian dana atau pembiayaan kepada pihak lain atas suatu benda atau barang yang akan dibeli atau dimiliki oleh pihak tersebut. Selain itu perusahaan juga melakukan kegiatan pembiayaan dalam bentuk penyediaan barang modal secara finance lease (kegiatan sewa guna usaha dimana penyewaan sewa guna usaha pada akhir masa kontrak mempunyai hak opsi untuk membeli objek sewa guna usaha berdasarkan nilai sisa yang disepakati bersama) maupun secara operating lease (kegiatan sewa guna, dimana penyewa guna usaha tidak mempunyai hak opsi untuk membeli objek sewa guna usaha). PT. Hasjrat Multifinance mempunyai fokus bisnis memberikan pembiayaan untuk pembelian kendaraan beroda dua dan empat yaitu untuk merk kendaraan Yamaha dan Toyota.

1. Struktur Organisasi dan Pembagian Tugas

PT. Hasjrat Multifinance berbentuk lini dengan 3 bagian utama yaitu bagian pemasaran,penagihan dan keuangan dan umum. Internal audit berada dibawah general manager yang berkantor di Jakarta. Organisasi lini adalah bentuk organisasi dimana hubungan antara atasan dan bawahan dilakukan secara langsung.

\section{Struktur Pengendalian Intern Aset tetap pada PT. Hasjrat Multifinance Cabang Manado}

1. Lingkungan Pengendalian

PT. Hasjrat Multifinance Cabang Manado menetapkan program pendidikan dan pelatihan selama 3 bulan untuk melengkapi kemampuan dasar yang berguna dalam menjalankan tugas. Sistem kontrak selama 1 tahun bagi karyawan baru yang diterapkan merupakan salah satu usaha manajemen mendorong terciptanya SDM yang baik yang bertujuan meningkatkan kinerja perusahaan.

2. Penilaian Resiko

- Tidak pernah dilakukan pengujian atas kemungkinan terjadinya penurunan nilai jika terdapat perubahan yang signifikan, baik dalam penggunaan aktiva atau perubahan dalam lingkungan bisnis.

- Tidak adanya pemisahan capital expenditure dan revenue expenditure untuk aset tetap sesuai PSAK No. 16

\section{Komunikasi dan Informasi}

Pencatatan aset tetap dimulai dari tahun 1997 s/d sekarang . Akan tetapi penelitian yang diambil hanya beberapa transaksi yang terdiri dari tahun 1997 s/d 2006 yaitu : 


\begin{tabular}{|c|c|c|c|c|c|c|}
\hline Nama & $\begin{array}{c}\text { Tgl } \\
\text { Perolehan }\end{array}$ & $\begin{array}{l}\text { Jml } \\
\text { unit }\end{array}$ & $\begin{array}{c}\text { Harga } \\
\text { Perolehan }\end{array}$ & $\begin{array}{c}\text { Sisa } \\
\text { masa } \\
\text { manfa } \\
t\end{array}$ & $\begin{array}{c}\text { \%Pen } \\
\text { yusuta } \\
\text { n }\end{array}$ & $\begin{array}{c}\text { Nilai } \\
\text { Buku } \\
(\mathbf{R p})\end{array}$ \\
\hline Printer laser jet $5 \mathrm{~L}$ & 1997 & 1 & 1.300 .000 & - & $12,5 \%$ & - \\
\hline Printer Epson LQ 2170 & 1997 & 1 & 1.575 .000 & - & $12,5 \%$ & - \\
\hline Komputer Pentium 3 & 2002 & 1 & 3.925 .000 & - & $12,5 \%$ & - \\
\hline Komputer pentium 4 & 2003 & 1 & 13.200 .000 & - & $12,5 \%$ & - \\
\hline UPS ICA & 2003 & 3 & 10.687 .500 & - & $12,5 \%$ & - \\
\hline UPS CT 682B & 2003 & 1 & 1.200 .000 & - & $12,5 \%$ & - \\
\hline Printer HP 2110 & 2003 & 1 & 2.330 .000 & - & $12,5 \%$ & - \\
\hline Printer HP Laser Jet 1010 & 2003 & 1 & 2.130 .000 & - & $12,5 \%$ & - \\
\hline Silver HP ML150 system & 2003 & 1 & 18.009 .400 & - & $12,5 \%$ & - \\
\hline Komputer Pentium 4 & 2003 & 1 & 3.700 .000 & - & $12,5 \%$ & - \\
\hline Komputer Pentium 4 Asus & 2004 & 1 & 7.600 .000 & - & $12,5 \%$ & - \\
\hline Note Book Compaq & 2004 & 1 & 11.375 .000 & - & $12,5 \%$ & - \\
\hline Printer HP 1010 & 2004 & 1 & 1.690 .000 & - & $12,5 \%$ & - \\
\hline Komputer HP 1010 & 2004 & 1 & 16.970 .430 & - & $12,5 \%$ & - \\
\hline Printer HP 3744 C & 2004 & 1 & 490.000 & - & $12,5 \%$ & - \\
\hline Printer Epson 2180 & 2005 & 1 & 5.722 .290 & - & $12,5 \%$ & - \\
\hline
\end{tabular}

Sumber : PT. Hasjrat Multifinance Cabang Manado

\section{Aktivitas Pengendalian}

Dilakukan berdasarkan sistem otorisasi dari pimpinan yaitu :

- Perbaikan dan pembelian aset tetap dan diotorisasi oleh bagian keuangan dan Direktur

- Pelepasan aset tetap diotorisasi oleh Direktur, kemudian bagian pembukuan melakukan proses penjurnalan. 


\section{Pemantauan}

Pemantauan pengendalian yang dilakukan tidak berjala dengan efektif. Hal tersebut terlihat dari :

1. Tidak pernah dilakukan pemeriksaan fisik aset tetap (setahun sekali) dan tidak diberikan penomoran

2. Tidak pernah dilakukan penghapusan Aset tetap yang nilai bukunya sudah habis dan yang sudah tidak bisa digunakan untuk operasional perusahaan, tetapi masih ada di dalam kartu kontrol aset tetap.

\section{Pembahasan}

\section{Analisa dan Evaluasi Struktur Organisasi}

Lingkungan Pengendalian Intern Aset tetap pada PT. Hasjrat Multifinance cabang Manado, sesuai struktur organisasi perlu dilakukan pemisahan tugas dan tanggung jawab antara bagian accounting dan bagian finance. Hal tersebut dilakukan karena setiap transaksi tidak boleh dilaksanakan dari awal sampai akhir oleh satu orang atau satu unit organisasi, tanpa ada campur tangan dari orang atau unit organisasi lain.

\section{Analisa dan Evaluasai Pengendalian Intern Aset Tetap}

\begin{tabular}{|c|c|c|}
\hline Teori & $\begin{array}{c}\text { Penerapan Pada PT Hasjrat } \\
\text { Multifinance Cabang } \\
\text { Manado }\end{array}$ & Hasil Analisis \\
\hline $\begin{array}{l}\text { Lingkungan } \\
\text { Pengendalian }\end{array}$ & Lingkungan Pengendalian & Lingkungan Pengendalian \\
\hline $\begin{array}{l}\text { 1. Falsafah manajemen } \\
\text { dan gaya operasi }\end{array}$ & 1. Mempunyai filosofi & $\begin{array}{l}\text { Baik, memiliki tujuan untuk } \\
\text { menjadi perusahaan pembiayan } \\
\text { terbesar di sulawesi utara. }\end{array}$ \\
\hline 2. Struktur Organisasi & $\begin{array}{l}\text { 2. Uraian tugas yang } \\
\text { berhubungan dengan } \\
\text { kebijakan aset tetap tidak } \\
\text { ada }\end{array}$ & $\begin{array}{l}\text { Tidak efektif, yang } \\
\text { mengakibatkan kurangnya control } \\
\text { kerja. }\end{array}$ \\
\hline 3. Komite Audit & $\begin{array}{l}\text { 3. Tidak mempunyai komite } \\
\text { audit }\end{array}$ & $\begin{array}{l}\text { 3. Tidak efektif, tidak adanya } \\
\text { komite audit menyebabkan } \\
\text { kurangnya pengawasan terhadap } \\
\text { aktivitas perusahaan menyangkut } \\
\text { tata tertib prosedur dan kebijakan } \\
\text { sehingga mempengaruhi penyajian } \\
\text { informasi laporan keuangan yang } \\
\text { relevan karena kemungkinan untuk } \\
\text { kesalahan pencatatan dan sistem } \\
\text { sangat tinggi }\end{array}$ \\
\hline $\begin{array}{l}\text { 4. Penetapan wewenang } \\
\text { dan tanggung jawab }\end{array}$ & 4. Terdapat rangka kerja & $\begin{array}{l}\text { 4. tidak efektif, Karena setiap } \\
\text { transaksi tidak boleh dilaksanakan } \\
\text { dari awal sampai akhir oleh satu } \\
\text { orang atau satu bagian }\end{array}$ \\
\hline
\end{tabular}




\begin{tabular}{|c|c|c|}
\hline 5. Fungsi Audit Internal & $\begin{array}{l}\text { Berkantor di Jakarta, } \\
\text { berkedudukan dibawah general } \\
\text { manager }\end{array}$ & $\begin{array}{l}\text { 5. tidak efektif, karena tidak bisa } \\
\text { melakukan audit terhadap general } \\
\text { manager, karena tidak independen } \\
\text { serta tidak dapat melakukan } \\
\text { pengawasan secara langsung } \\
\text { terhadap terhadap setiap bagian- } \\
\text { bagian yang ada dalam lingkungan } \\
\text { perusahaan. }\end{array}$ \\
\hline $\begin{array}{l}\text { 6. Praktek dan } \\
\text { kebijakan karyawan }\end{array}$ & $\begin{array}{l}\text { 6. Tidak memiliki program } \\
\text { pelatihan untuk karyawan }\end{array}$ & $\begin{array}{l}\text { 6. Tidak efektif, karena untuk } \\
\text { mencapai tujuan perusahaan, } \\
\text { disetiap tingkat organisasi harus } \\
\text { memiliki pengetahuan dan } \\
\text { ketrampilan }\end{array}$ \\
\hline $\begin{array}{l}\text { 7. Metode Pengendalian } \\
\text { Manajemen }\end{array}$ & $\begin{array}{l}\text { 7. tidak pernah dilakukan } \\
\text { pemeriksaan fisik aktiva tetap } \\
\text { (setahun sekali) }\end{array}$ & $\begin{array}{lr}\text { Tidak efektif, karena untuk } \\
\text { mencegah terjadinya penggelapan, } \\
\text { kecurangan } \\
\begin{array}{l}\text { penyelewengan } \\
\text { perusahaan. }\end{array}\end{array}$ \\
\hline
\end{tabular}

\begin{tabular}{llll}
\hline Penilaian Resiko & Penilaian Resiko & Penilaian Resiko \\
\hline $\begin{array}{l}\text { 1. Kebijakan Akuntansi } \\
\text { (penurunan nilai aset } \\
\text { tetap) }\end{array}$ & $\begin{array}{l}\text { 1. Tidak pernah melakukan } \\
\text { pengujian penurunan nilai } \\
\text { aset tetap sesuai PSAK 48 }\end{array}$ & $\begin{array}{l}\text { 1. Aset tetap yang dicatat pada } \\
\text { laporan keuangan belum } \\
\text { mencerminkan nilai buku yang } \\
\text { sebenarnya. }\end{array}$ \\
\hline $\begin{array}{l}\text { 2. Perubahan standar } \\
\text { akutansi }\end{array}$ & $\begin{array}{l}\text { 2. tidak dilakukan perubahan } \\
\text { untuk pengeluaran aset tetap, } \\
\text { semua pengeluaran aset tetap } \\
\text { dibebankan langsung pada } \\
\text { pengeluaran pendapatan } \\
\text { (revenue expenditure) }\end{array}$ & $\begin{array}{l}\text { 2. Tidak efektif karena semua } \\
\text { pengeluaran aset tetap dibebankan } \\
\text { langsung pada pengeluaran } \\
\text { pendapatan (revenue expenditure) } \\
\text { tetapi dapat juga dijadikan sebagai } \\
\text { pengeluaran modal (capital } \\
\text { expenditure) }\end{array}$ \\
\end{tabular}

\begin{tabular}{|c|c|c|}
\hline Aktivitas Pengendalian & Aktivitas Pengendalian & Aktivitas Pengendalian \\
\hline $\begin{array}{l}\text { Otorisasi Transaksi } \\
\text { terhadap aset tetap }\end{array}$ & $\begin{array}{l}\text { 1. Setiap transaksi yang } \\
\text { berhubungan dengan aset } \\
\text { tetap } \\
\text { (perbaikan,pembelian,pelep } \\
\text { asan) selalu di otorisasi } \\
\text { oleh direktur }\end{array}$ & $\begin{array}{l}\text { 1. Baik adanya untuk mencegah } \\
\text { terjadinya } \\
\text { wewenang }\end{array}$ \\
\hline $\begin{array}{l}\text { 2. Pengawasan terhadap } \\
\text { aset tetap }\end{array}$ & $\begin{array}{l}\text { 2. Aset tetap perusahaan tidak } \\
\text { diberikan penomoran }\end{array}$ & $\begin{array}{l}\text { 2. Tidak efektif karena tidak bisa } \\
\text { mendeteksi adanya kehilangan } \\
\text { terhadap aset tetap }\end{array}$ \\
\hline
\end{tabular}




\begin{tabular}{|c|c|c|}
\hline $\begin{array}{l}\text { 3. Pengendalian Fisik } \\
\text { terhadap aktiva tetap }\end{array}$ & $\begin{array}{l}\text { 3. tidak pernah dilakukan } \\
\text { pencocokan aset tetap secara } \\
\text { fisik dengan kartu aset tetap }\end{array}$ & $\begin{array}{l}\text { 3. Tidak efektif, karena untuk } \\
\text { mencegah terjadinya penggelapan, } \\
\text { kecurangan } \\
\begin{array}{l}\text { penyelewengan ataupun } \\
\text { perusahaan. }\end{array}\end{array}$ \\
\hline $\begin{array}{l}\text { Pengendalian fisik atas } \\
\text { catatan aset tetap }\end{array}$ & $\begin{array}{l}\text { Aset tetap untuk pembelian } \\
\text { tidak menggunakan persetujuan } \\
\text { anggaran }\end{array}$ & $\begin{array}{l}\text { Tidak efektif, karena setiap } \\
\text { pengeluaran harus dianggarkan }\end{array}$ \\
\hline \multirow{3}{*}{$\begin{array}{l}\text { Informasi dan } \\
\text { Komunikasi } \\
\end{array}$} & Informasi dan Komunikasi & Informasi dan Komunikasi \\
\hline & $\begin{array}{l}\text { 1. Metode yang digunakan } \\
\text { menggunakan metode garis } \\
\text { lurus sesuai dengan PSAK } \\
\text { dan dilakukan secara } \\
\text { konsisten }\end{array}$ & $\begin{array}{l}\text { 1. Sudah baik, karena } \\
\text { pembebanan penyusutan } \\
\text { merupakan pengakuan } \\
\text { terjadinya penurunan nilai } \\
\text { atas potensi suatu aktiva }\end{array}$ \\
\hline & $\begin{array}{l}\text { 2. Daftar aset tetap tidak up } \\
\text { todate }\end{array}$ & $\begin{array}{l}\text { 2. Tidak efektif, karena aset tetap } \\
\text { perusahaan harus memberikan } \\
\text { informasi yang akurat terhadap } \\
\text { keberadaan aktiva tersebut }\end{array}$ \\
\hline \multirow[t]{2}{*}{ Pemantauan } & Pemantauan & Pemantauan \\
\hline & $\begin{array}{l}\text { 1. Proses pengawasan yang } \\
\text { dilakukan terhadap aset } \\
\text { tetap belum terorganisir }\end{array}$ & $\begin{array}{l}\text { Tidak efektif karena akan } \\
\text { berdampak terhadap efisiensi } \\
\text { dan efektivitas dan kualitas } \\
\text { kegiatan } \\
\text { perusahaan. }\end{array}$ \\
\hline
\end{tabular}

Sumber : Hasil Olahan Data

Berdasarkan hasil olahan data diatas terlihat bahwa struktur pengendalian intern aset tetap yang diterapkan oleh perusahaan belum efektif. Hal ini terlihat dari penyelenggaraan unsur-unsur pengendalian intern aset tetap yang ada yaitu :

\section{Lingkungan Pengendalian}

Lingkungan pengendalian belum efektif, belum memiliki program pelatihan dan kompetensi untuk meningkatkan kemampuan para karyawannya sesuai dengan tujuan organisasi. karyawan adalah salah satu bentuk asset internal yang paling berharga dimiliki oleh perusahaan. Artinya dengan kebijakan dan usaha kuat untuk selalu menjaga dan mempertahankan karyawan maka diharapkan akan mampu menghindari faktor-faktor yang mengakibatkan tidak tercapainya tujuan organisasi.

\section{Penilaian Resiko}

Penerapan penilaian resiko untuk asset tetap belum efektif, manajemen perusahaan tidak pernah melakukan pengujian terhadap asset tetap. Tujuannya agar asset tetap yang disajikan dalam laporan keuangan tetap mencerminkan kewajaran sumber daya ekonomik. 


\section{Aktivitas Pengendalian}

- Sistem otorisasi terhadap transaksi aset tetap sudah baik. Setiap transaksi dilakukan atas dasar otorisasi oleh Direktur dan bagian-bagian lain yang memiliki wewenang.

- Pengawasan terhadap aset tetap masih belum efektif, karena setiap aset tetap tidak diberikan penomora serta tidak pernah melakukan pencocokan aset tetap, yang mengakibatkan tidak diketahui berapa banyak aset tetap perusahaan yang masih digunakan atau sudah tidak digunakan.

\section{Informasi dan Komunikasi}

- Metode Penyusutan Aset Tetap

Menggunakan metode penyusutan metode garis lurus dengan tarif penyusutan kendaraan roda 2 (dua) 12,5\%, kendaraan roda 4 (empat) $25 \%$ dan inventaris kantor $12,5 \%$.

- Daftar Aset Tetap tidak Up Todate

Manajemen perusahaan tidak pernah memberikan informasi tentang keberadaan aset tetap. Hal tersebut terlihat dari kurangnya kontrol untuk setiap aset tetap, sehingga aset tetap yang disajikan di dalam laporan keuangan belum menyajikan nilai buku (book value) dari aktiva tersebut.

\section{Pemantauan Pengendalian}

Pimpinan perusahaan bertanggungjawab penuh dalam usaha pengawasan internal terhadap aset tetap. Manajemen perlu memperhatikan dan menentukan cara yang baik dalam menciptakan sistem pengawasan yang efektif dan efisien agar pelakanaan prosedurprosedur pengawasan dapat dilaksanakan sebaik mungkin.

\section{KESIMPULAN}

Penelitian yang dilakukan oleh penulis, dapat disimpulkan bahwa pengendalian intern yang diterapkan pada PT. Hasjrat Multifinance cabang Manado belum efektif berjalan dengan baik. Hal tersebut dapat dilihat dari lingkungan pengendalian, tidak ada pemisahan tugas dan tanggungjawab antara bagian accounting dan finance, tidak adanya komite audit yang mengakibatkan kurangnya pengawasan terhadap aktivitas perusahaan.

Penilaian resiko yang dilakukan belum efektif, manajemen perusahaan tidak pernah melakukan pengujian terhadap asset tetap begitu juga dengan aktivitas pengendalian terhadap asset tetap sudah berjalan dengan baik, karena setiap transaksi yang berhubungan dengan asset tetap selalu diotorisasi oleh Direktur tetapi untuk pengawasan terhadap asset tetap belum efektif karena aset tetap perusahaan tidak diberikan penomoran dan tidak pernah dilakukan pemeriksaan fisik terhadap asset tetap.

Pencatatan yang dilakukan untuk asset tetap belum memberikan informasi yang akurat terhadap keberadaan dari asset tetap yang disajikan dalam laporan keuangan serta kurangnnya pemantauan yang dilakukan oleh manajemen perusahaan yang yang berhubungan dengan efisiensi dan efektifitas operasional perusahaan.

Hasil pembahasan dengan melihat kondisi perusahaan, maka penulis menyarankan beberapa hal yang harus diperbaiki yaitu :

1. Perlu ada pembenahan di dalam struktur organisasi perusahaan, antara fungsi accounting dan finance, perlu ada pemisahan tugas dan tanggung jawab yang tidak dikerjakan oleh satu orang serta peran komite audit untuk melakukan pengawasan terhadap aktivitas perusahaan.

2. Menerapkan program pelatihan dan pengembangan terhadap setiap karyawan, 
3. Membuat pemisahan pengeluaran modal (capital expenditure) dan pengeluaran pendapatan (revenue expenditure)

4. Dilakukan pencocokan fisik aset tetap dengan kartu aset tetap agar jumlah atau nilai aset tetap yang dilaporkan teruji kebenarannya.

\section{DAFTAR PUSTAKA}

Cahyadi, Indra Andreas, 2011. Analisis Pengujian Pengendalian Aset tetap pada STIKES Perdhaki Charitas Palembang. Skripsi Palembang http://eprints.mdp.ac.id/721/1/Jurnal\%20Indra\%20Cahyadi\%20.pdf.

Dunia Firdaus A. 2010. Ikhtisar Lengkap Pengantar Akuntansi Edisi Ketiga. Fakultas Ekonomi Universitas Indonesia. Jakarta

Fariyanti, R. (2013), “ Analisa Keefektifan Pengendalian Internal Sistem Persediaan

Giri Efraim Ferdinan. 2012. Akuntansi Keuangan Menengah 1. Jogjakarta: UPP STIM YKPN

Halim, Abdul 2008, Auditing: Dasar-Dasar Audit Laporan Keuangan, UPP STIM YKPN, Yogyakarta

Hery,SE.,MSi _, 2011, Akuntansi Aktiva,Hutang dan Modal, Edisi Kesebelas, Penerbit Gava Media, Jakarta

Ismail.2010. Akuntansi Bank. Surabaya: PT Kencana

Ikatan Akuntan Indonesia. 2012. Standar Akuntansi Keuangan. Ikatan Akuntan Indonesia. Jakarta

Mulyadi. (2008), Sistem Akuntansi, Edisi 3, Bagian Penerbitan Sekolah Tinggi Ilmu Ekonomi YKPN, Yogyakarta.

Messier, William F, Jr., et al 2009, Jasa Audit \& Assurance Pendekatan Sistematis, Jilid 1, Salemba Empat, Jakarta.

Mihaela, D., and lulian, S. (2012)," Internal Control and the Impact on Corporate Governance in Romanian Listed Companies, “ Journal of Eastern Europe Research in Business \& Economic. (tidak dipublikasikan)

Santosa,Syahmi Muhammad, 2014. Peranan Sistem Pengendalian Intern Aset tetap Terhadap Pengelolaan Aset Tetap Perusahaan Daerah Air Minum (PDAM) Pekalongan. Skripsi Pekalongan. http://mahasiswa.dinus.ac.id/docs/skripsi/abstrak/14619.pdf.

Suwardjono, 2013, Akuntansi Pengantar, Edisi Keenam, Penerbit BPFE-Yogyakarta

Suherman Ade,2011. Pengendalian Intern Aset tetap pada PDAM Tirta Anom Banjar.http://adesuherman.blogspot.co.id/2012/10/analisis-strukturpengendalian-intern_22.html.

Skousen Fred, Stice Earl K dan Stice James D. 2011. Akuntansi Keuangan Menengah. Salemba Empat. Jakarta

Sunyoto Danang,SH.,SE.,M.M_ 2014, Auditing Pemeriksaan Akuntansi. Jilid I. Penerbit Center of Academic Publishing Service. Yogyakarta: 